\title{
The Impact of Investment in Creative Activities on Turnover Stock Ratio: An Empirical Evidence of Jordanian Banking
}

\author{
Faris Nasif AL- Shubiri ${ }^{1} \&$ Ziad Mohammad AL-saidat ${ }^{2}$ \\ ${ }^{1}$ Department of Finance and Banking, College of Business, Amman Arab University, Jordan \\ 2 Department of Accounting, College of Business, Amman Arab University, Jordan \\ Correspondence: Faris Nasif AL- Shubiri, Department of Finance and Banking, College of Business, Amman Arab \\ University, P.O box: 230094- Code 11123, Jordan. E-mail: fa_shub@yahoo.com
}

Received: August 28, 2013

Accepted: September 25, 2013

Online Published: November 8, 2013

doi:10.5430/ijba.v4n6p134

URL: http://dx.doi.org/10.5430/ijba.v4n6p134

\begin{abstract}
This study explains the impact of investment in creative activities on turnover stock ratio of 13 commercial banks listed in Amman Stock Exchange (ASE) during the period from 2001 to 2011. The concept of creativity reflect all activities in the banking sector, which is considered an indicator of growth in all of the services provided by banks from different banking operations and working to maintain competitiveness in the market index.

The results indicate the contextual variables are more negative and significant impact on turnover stocks but low significant impact of external communication variables and there is no significant level for internal competence variables and strategic variables on turnover stocks. This study has shown that the contextual variables and external communication variables support innovative activities and plays a crucial role for support decision making in banks more than strategic variables and internal competence variable.
\end{abstract}

Keywords: investment, creative activities, turnover stock ratio, banking, Jordan

\section{Introduction}

Investment in capital lead to a growth in the assets of the company as a clear impact on stock returns and contributes to determine the pricing of products or services provided by companies. Anderson and Garcia-Feijoo, (2006), Cooper, Gulen and Schill, (2008). Recently, there are more of empirical papers are highlighting a negative sign between investment and capital assets with non-normal returns for stocks. Asset growth is increasing due to the growing proportion of creativity used, whether financial or non-financial terms have been discussed in a lot of literature about the importance of innovation in financial companies, Lea (1996). Although the financial innovation enters into everything, but it has recently become the financial instruments included in the financial markets, as is also found in banks through the ATM and Internet services and modern techniques used.

The innovation measured through research and development carried out by the companies as well as patents, intangible assets, these variables reflect on the success of the companies and gives the value of which leads to improved performance over the long term. It is difficulties in measuring it and gives a competitive advantage over rival companies, allowing them to stay longer in the market where multiple factors that creativity in companies affect the revenues and shares of companies in the market. There are small businesses that operate on the concept of creative activities, especially those that recently entered the market. Companies explain a vital point in the growth of their assets where the stages of creativity begins by having an idea or an opportunity for growth and that can be developed in the world economy and business manner. We note that creativity alone does not lead to technology through new markets, but also is a source of new ideas, which is the stage of creativity, a process that is central to economic growth (Schumpeter, 1942). Innovation is an important phenomenon in the modern economy despite the fact that the standard microeconomic theory focuses on the individual item or to obtain scarce resources and also seeking to achieve distributional efficiency and technical based on the evaluation of performance varies depending on many variables, including innovation. Of course, refers to the importance of financial innovation, which is the gateway for each production activity as well it might work to encourage savings and decisions that contribute to more productive and positive as these decisions contribute indirectly to the financial and creativity Levine, (1997). In 
this study we will examine the impact of investment in creative activities and turnover stock ratio in commercial banking of Jordan.

\section{Theoretical Framework}

\subsection{What Is Innovation?}

The concept of innovation expresses process stages is how companies can learn their tasks and how well the company can think of internal and collectively in addition to the possibility of internal stimulation of the right emphasis on creativity, Pavitt, (2003). Financial innovations can be grouped new operations such as products, services, organizational structures. At the financial system operations contain initial cost of the resources, including manpower, raw materials, capital and land and regulator, which can be done through financial institutions and brokers for securities where the properties of finance that it is working under the uncertainty, Cooper, Gulen and Schill, (2008).

Financial innovation is invaluable they express a new idea and illustrates the ambiguity in any process and contributes to the development of communities that the concept of Schumpeter in innovation as "creative destruction", which sheds light on the mystery: Companies creative you provide new products or better technology in the economy, but this destroys stagnant companies where such destruction that is the negative side of innovation. Based financial management function in building a financial system that runs on the distribution of resources on all the production process also constantly trying to study the changing environment and diagnosed to find appropriate solutions. This section indicates transfer of resources from savers to investors and then collects savings, and reduces risk through diversification and insurance, Merton, (1992).

\subsection{Activities of Innovation}

Souitaris, (2002) present many activities for innovation and divided to groups as:

Contextual variables: This concept is at the level of the company's strategy and its organizational structure, such as size and growth, age, income and profitability and other factors may also be at the level of the business environment, including manpower in the market, market conditions, and the technology used.

Strategic variables: This concept includes the main business network of the company and the environment, which is on the basis of which the design of the organizational structure processes and include expansion joints and R \& D operations.

Internal competence variables: This includes serving as the technical capabilities of the employees and the company as well as expertise and products that produce a function of the strategy that promotes the concept of creativity and includes employees and regulations.

External communication variables: This includes working the company's ability to interact with external information and foreign parties and how the company can expand and increase market share where the company through this factor is the development of relations with suppliers, customers and markets, and an exchange of knowledge with the growing branches.

\subsection{Literature Review}

Geroski (1994) explained that companies producing creativity and in the best in terms of performance companies, especially in economic recession and this confirms that the characteristics of the company an important role leads to creativity and not to the incentives and opportunities and therefore the companies that organize themselves to respond to the incentives and opportunities existing in the market to fit into the innovations of value to the company .The study recommended, there is a need to search in the company's properties, especially in the organizational structures.

In this study its recommendations to change the organizational structure, which has been a partial reference to him in our paper through a variable number of employees.

Saloner and Shepherd (1995) explained the process of adopting concept of ATM as a technological process depends on many external factors of the circumstances customer and the need for this service and benefits available and the time required to perform this service all of these factors depend on the extent of the bank in the particular area. ATM, while depositors relationship negative with cash machines. Lang, and Nolle (2000) analyze data of banking about the internet services and they find that a bank's choice a services through electronic banking operations depend on the nature and circumstances of the section on customers, which contributes to get extraordinary income also found that it is positively associated with increased branch banking operations. Sullivan (2000) came at a comparative study 
between the banks that operate on websites that do not work and the results of the study is a moral high degree in the sample which has a degree high are using the web-sites from other classes and other population, also found that it could achieve its benefits and income is phenomenal. Mantel and McHugh (2001) presented how to use the mail to pay bills by customers electronically and all relevant processes Visa credit ceilings city where the results of the study was a positive relationship statistically significant for age, sex, income.

In the previous studies he focused on technology as a creative, both in the way of lending or paying bills or any other electronic services provided to customers while our study focused on the variable of research and development, which is important in measuring technology and the use of banks for studies and research, which is the path to creativity.

Lerner (2002) examined the activities of the investment banks. The results of the study is a positive relationship with a significant degree also found that academics is not linked to the financing of institutions and therefore do not impact on the volume of transactions that take place in institutions. Shortridge (2004) finds successful investments projects result is a positive because the capital market reaction and this is not clear and the results that R\&D is could be misleading. Ramb and Reitzig (2005) explained the importance of R \& D to improve accounting practices form traditional to modern standards and its impact on expenses which leads to improve the company's market value. Cooper et al., (2008), examined the asset growth anomaly and find the negative correlation between asset growth and subsequent abnormal returns and the asset growth anomaly is essentially restricted to firms that have low innovative capacity and exhibit high asset growth and there are significantly positive abnormal returns in the fourth and fifth year after the asset growth.

Note of during the previous studies that tried to explain the correlation between the growth of assets and abnormal returns that can be achieved and thus used variable assets, which is considered an important measure of the size of our study which has use.

Cooper and Priestly (2011) present the compatibility between the company's operations in clarifying how the growth of assets based abnormal growth. Xing (2008), Chen, Novy-Marx and Zhang, (2011) is explain the importance of variable where different investment returns in the investment portfolio, where returns are higher in the shares of low investment. In general from previous studies they used different variables to some extent for the variables of our study, but we can say that the current study was characterized by building strategies for creativity after revision a literature review and measured by variables process quantity and applied to the financial market of Jordan ( bank sector), which is play a vital role in the economic sector in Jordan and upon which the majority of private institutions and adopted by the government in infrastructure financing.

\section{Methodology}

\subsection{Population and Sample}

The population of Jordanian commercial banking is 13 banks and the study used all population for the period 2001-2011 listed on Amman Stock Exchange, the banks are: Arab Jordan Investment Bank, Capital Bank of Jordan, Jordan Commercial Bank, Arab Banking Corporation, /(Jordan), Bank of Jordan, Societe Generale De Banque Jordanie, Arab Bank, The Hosing Bank For Trade and Finance, Invest Bank, Jordan National Bank, Jordan Kuwait Bank, Union Bank, Cairo Amman Bank.

\subsection{Hypotheses}

After study all theoretical framework and literature review, you can summarize the hypotheses as the following:

H0-1: There is no statistical significant impact of contextual variables on turnover stock ratio of Jordanian banking

H0-2: There is no statistical significant impact of strategic variables on turnover stock ratio of Jordanian banking

H0-3: There is no statistical significant impact of internal competence variables on turnover stock ratio of Jordanian banking

H0-4: There is no statistical significant impact of external communication variables on turnover stock ratio of Jordanian banking

H0-5: There is no statistical significant impact of investment in creative activities on turnover stock ratio of Jordanian banking

\subsection{Variables and Model of Study}

The independent variables explain for the following: 
Contextual variables (CV) measured by innovative bank a large of size (Log of Total Assets)

Strategic variables (SV) measured by innovative bank include R\&D strategy in business

Internal competence variables (ICV) measured by innovative bank have more human resources

External communication variables (ECV) measured by innovative bank have more branches

$$
\text { Turnover Stock Ratio }(T S R)=a_{0}+\beta_{1} C V+\beta_{2} S V+\beta_{3} I C V+\beta_{4} E C V+e_{i t}
$$

\section{Empirical Results}

Table 1 show the results of the descriptive statistics for independent variables contextual, strategic, internal competence, external communication variables and dependent variable turnover stock ratio and presents the means, standard deviation, minimum and maximum value of the variables. The high mean, standard deviation and maximum variables results are show for the variable of strategic variables as $492.62-653.03-3333.21$ respectively, but the low results on mean for internal competence variables as 0.0759 and standard deviation and maximum for external communication variables as $0.07429-0.29$ respectively, but the high ratio in Minimum for contextual variables as 7.73 and low for strategic variables as 0.00

Table 1. Descriptive statistics

\begin{tabular}{llllll}
\hline Variable & TSR & CV & SV & ICV & ECV \\
\hline Mean & 23.378 & 9.007 & 492.62 & 0.0759 & 0.0769 \\
Standard Deviation & 28.49 & 0.5294 & 653.03 & 0.09843 & 0.07429 \\
Minimum & 0.17 & 7.73 & 0.00 & 0.01 & 0.01 \\
Maximum & 182.39 & 10.38 & 3333.21 & 0.42 & 0.29
\end{tabular}

Table 2 show the results of regression analysis of each independent variable and turnover stock ratio as dependent variable and the results indicate the contextual variables is high and negative significant at $\mathrm{t}=-3.114$ and $(\mathrm{sig}=0.002)$ at level $1 \%$. Then external communication variables also negative but low significant at $\mathrm{t}=-1.800(\mathrm{sig}=0.074)$ at level 10\%. The results also show no significant impact on strategic variables, internal competence variables and turnover stock ratio. Then in this study the researchers used correlation test suggests that a significant relationship may exist between successful development of contextual variables and turnover stock ratio at significant $\mathrm{R}=0.254$. The correlations between ECV, and turnover stock ratio were low and significant at $\mathrm{R}=0.150$, whereas correlation very low on SV and ICV and turnover stock ratio. Finally, the size of the institution or the bank is a good point in taking into account the operation of creativity as the granting credit indicator in the process of creativity. If credit greater than the competitive edge which affects the increase in revenue and achieve economies of scale that contribute to creating new ideas contribute to the creative process and that enhance competition in the market Note that many banks are acting cash flow and liquidity their existing through retained by cash reasonable for the purposes of investment and expansion and exploitation of opportunities and thus can be considered this activity creative as banks can be played by moving the capital and cash through international trade in terms of difficulty do and the establishment of global markets monopolized, so allowing banks to carry out its functions efficiently and effectively and are able to measure the risk of time and the appropriate form.

Table 2. Regression analysis

\begin{tabular}{lllllll}
\hline Variable & $\mathbf{R}$ & $\mathbf{R}^{2}$ & $\mathbf{T}$ & Sig & St- Error & B \\
\hline CV & 0.254 & 0.064 & -3.114 & $0.002 * * *$ & 4.384 & -13.654 \\
SV & 0.109 & 0.012 & 1.304 & 0.194 & 0.004 & $4.764 \mathrm{E}-03$ \\
ICV & 0.133 & 0.018 & -1.596 & 0.113 & 24.165 & -38.565 \\
ECV & 0.150 & 0.022 & -1.800 & $0.074 *$ & 31.940 & -57.496 \\
\hline
\end{tabular}

Note: Asterisks $(* * *),(* *)$ and $(*)$ indicates significance at $1 \%, 5 \%$ and $10 \%$ respectively

Table 3 shows the multiple regression tests for the four variables of innovation activities process as independent variables. To predict the regression model, the multiple correlation coefficient $(R)$, coefficient of determination $\left(R^{2}\right)$, and $F$-test were examined. First, the $F$ - test model, explained, had a value of $4.232(\mathrm{p}=0.003)$ and was considered high significant at 0.000 . Also in this table show the $R$ of independent variables on the dependent variable is 0.331 , and the $R^{2}$ is 0.109 . This result is interpreted when it was taking all the variables combined with the dependent variable. in the sense that the impact of variable size of assets with a variable number of bank branches had high 
significant, which is reflected in the acceptance of alternative hypothesis and explains the interest banks of increase the number of branches to provide more and better to attract many customers, which is reflected impact on the turnover stock ratio in addition to that banks are exploiting the use of assets in an optimal way for the purposes of expansion in spite of the lack of interest observed in the research and development as well as working in banks.

Table 3. Multiple regression analysis

\begin{tabular}{lllll}
\hline Variable & $\mathrm{R}$ & $\mathrm{R}^{2}$ & $\mathrm{~F}$ & $\mathrm{Sig}$ \\
\hline Total Independent Variables & 0.331 & 0.109 & 4.232 & $0.003^{* * *}$ \\
\hline
\end{tabular}

Note: Asterisks $(* * *),(* *)$ and $(*)$ indicates significance at $1 \%, 5 \%$ and $10 \%$ respectively

\section{Conclusion}

Innovative activities very important to know and this is reflecting to turnover stocks and returns. The adoption of the concept of creative activities in banks contribute to the survival of banks in the market and give it a competitive advantage over other banks as to be a magnet for big customers and talented because many customers want excellent services, quickly and accurately in the achievement even if costs rose slightly. The results indicate the contextual variables are more negative and significant impact on turnover stocks but low significant of external communication variables and there is no significant level for internal competence variables and strategic variables on turnover stocks. This study has shown that the contextual variables and external communication variables support innovative activities and plays a crucial role for support decision making in banks more than strategic variables and internal competence variable. According to external communication variable, Innovative banks have strong and good communication with the stockholder relationships as owners to maximize the value wealth, more than non innovative banks. But in results shows the lbanking industry is still need networking scanning external information and cooperation, organizing with other external banks.

The results show a weakness in the using of $\mathrm{R} \& \mathrm{D}$ operations and also a weakness when take human resources variable on turn over stock ratio with banks in an effective and influential note but this sector is very important in the Jordanian economy which must continue to research and development leading to the development of the service provided and improves the quality of banking operations so there is an impact on the stock market.

This means there are other factors that affect of movement of turnover stock which banks should strengthen its role in the market and with competitors good relations so there is an essential role for the number of branches in terms of size contribute positively as could be the role of culture in the behavior and strengthen banks' operations in the market. Where it is noted from the results of the study, said a prominent role in the impact on turnover stock ratio is the size of the bank and which is no doubt that the financial system in Jordan practiced a big role in the Jordanian economy as the size of the bank is a standard survival and continuity in the market and helps to competition, especially in recent times, which witnessed the entry of foreign banks in the commercial capital of Islamic large and distinctive quality of services. Finally, a competitive banking financial system helps innovative small banks players to grow at large quickly, accurate and established wealth. Banks innovative capacity therefore appears to play vital role in the Jordanian economy.

\section{References}

Anderson, C., \& Garcia-Feijoo, L. (2006). Empirical evidence on capital investment, growth options, and security returns. Journal of Finance, 61, 171-194 http://dx.doi.org/10.1111/j.1540-6261.2006.00833.x

Chen, L., Novy-Marx, R., \& Zhang, L. (2011). An alternative three-factor model. Working Paper, OhioState University. http://dx.doi.org/10.1111/j.1468-036X.2011.00628.x

Cooper, I., \& R. Priestly. (2011). Real investment and risk dynamics. Journal of Financial Economics, 101, $182-205$ http://dx.doi.org/10.1016/j.jfineco.2011.02.002

Cooper, M., Gulen, H., \& Schill, M. (2008). Asset growth and the cross section of stoc returns. Journal of Finance, 63, 1609-1651. http://dx.doi.org/10.1111/j.1540-6261.2008.01370.x

Geroski, Paul A. (1994). Market structure, corporate performance and innovative activity. Oxford University Press, Clarendon Press. Oxford and New York - \& Dewey Number 338.0640941.

Lea, Michael. (1996). Innovation and the Cost of Credit: A Historical Perspective. Housing Policy Debate, 7 , 147-174. http://dx.doi.org/10.1080/10511482.1996.9521216 
Lerner, Josh. (2002). Where Does State Street Lead? A First Look at Finance Patents, 1971-2000. Journal of Finance, 57, 901-930. Working Paper No 7918. http://dx.doi.org/10.2139/ssrn.224895

Levine, Ross. (1997). Financial Development and Economic Growth Financial Development and Economic Growth: Views and Agenda. Journal of Economic Literature, 35(June), 688-726. http://dx.doi.org/10.1596/1813-9450-167

Mantel, Brian, \& Timothy McHugh. (2001). Competition and Innovation in the Consumer e Payments Market? Considering Demand, Supply, and Public Issues. Federal Reserve Bank of Chicago, Emerging Payments Occasional Working Paper Series (EPS-2001-4). http://dx.doi.org/10.2139/ssrn.298388

Merton, Robert C. (1992). Financial Innovation and Economic Performance. Journal of Applied Corporate Finance, 4(Winter), 12-22. http://dx.doi.org/10.1111/j.1745-6622.1992.tb00214.x

Pavitt, K. (2003). The Process of Innovation SPRU Electronic. Working paper, Series Paper, N89. Retrieved from http://www.sussex.ac.uk/spru

Ramb, F., \& Reitzig, M. (2005). Comparing the Value Relevance of $R \& D$ Reporting in Germany: Standard andSelection Effects. Discussion Paper Deutsche Bundesbank, Series 1: Economic Studies ISBN 3-86558-092-0.

Saloner, Garth, \& Andrea Shepard. (1995). Adoption of Technologies with Network Effects: An Empirical Examination of the Adoption of Automated Teller Machines. Rand Journal of Economics, 26(Autumn), 479-501.

Schumpeter, Joseph Alois. (1942). Capitalism, socialism, and democracy. New York Harper \& brosShaver, J.

Shortridge, R. T. (2004). Market Valuation of Successful versus Non-successful R\&D Efforts in the Pharmaceutical Industry. Journal of Business Finance \& Accounting, 31, 1301-1326. http://dx.doi.org/10.1111/j.0306-686X.2004.00575.x

Souitaris, V. (2002). Technological trajectories as moderators of firm level determinates of innovation. Research policy, 31, 877- 899. http://dx.doi.org/10.1016/S0048-7333(01)00154-8

Sullivan, Richard J. (2000). How Has the Adoption of Internet Banking Affected Performance and Risk in Banks? Financial Industry Perspectives, Federal Reserve Bank of Kansas City, 1-16Saloner. http://dx.doi.org/10.1016/j.jbankfin.2006.10.003

Xing, Y. (2008). Interpreting the value effect through the q-theory: An empirical investigation. Review of Financial Studies, 21, 1767-1795. http://dx.doi.org/10.1093/rfs/hhm051 